Received 01.04.2017 Reviewed 21.04.2017 Accepted 24.04.2017

A - study design

B - data collection

C - statistical analysis

D - data interpretation

$\mathbf{E}$ - manuscript preparation

F - literature search

\title{
The size of the external patchwork of fields as an indicator of the need for land consolidation and exchange in the villages of the commune of Drzewica
}

\author{
Przemysław LEŃ ABCDEF $₫$
}

University of Life Sciences in Lublin, Faculty of Production Engineering, ul. Leszczyńskiego 7, 20-069 Lublin, Poland; e-mail: przemysław.len@up.lublin.pl

For citation: Leń P. 2017. The size of the external patchwork of fields as an indicator of the need for land consolidation and exchange in the villages of the commune of Drzewica. Journal of Water and Land Development. No. 33 p. 99-106. DOI: 10.1515/jwld-2017-0024.

\begin{abstract}
Land consolidation and exchange have a significant impact on improving the spatial structure of rural areas in Poland. Given the fact that agricultural areas in different regions of Poland are characterized by different spatial and technical parameters and different legal and land-ownership-related conditions, it is necessary to conduct investigations and analyses focused on selecting the optimum features describing a given area. As demonstrated by previous studies, the areas located in central Poland are characterized by a defective land ownership pattern with an external patchwork of fields. Therefore, it is necessary to carry out studies to determine the size of that external patchwork of land ownership and to propose solutions for its liquidation. The analyses reported in this article clearly show that in the area studied, priority should be given to land exchange followed by land consolidation.
\end{abstract}

Key words: land consolidation, land exchange, land owned by non-residents, patchwork of fields

\section{INTRODUCTION}

The approach to land consolidation projects should be complex, as these are multifunctional actions related to the improvement of inadequate agricultural land use structure and the implementation of sustainable multifunctional rural development policy [STAŃCZUK-GAŁWIACZEK 2016] inter alia in the economic, social or environmental sphere [TRYSTUŁA 2008].

In central Poland, the spatial structure of rural areas has been shaped by historical factors and socioeconomic and demographic processes [WÓJCIK, LEŃ 2015], with the last two still having an important impact on on-going changes. The faulty land ownership structure makes land use in rural areas problematic, translating into poor agricultural development of these areas. In the Łódź Province, farms are mostly owned by individual farmers. Due to the large fragmentation of farm-holdings, agricultural production is associated with high costs, which, among others, are a consequence of inefficient use of agricultural machines and poor access from homestead to fields. Ownership of land by people who live in a different village than the one in which their fields are situated leads to a growing need to consolidate, and, above all, exchange land, in order to improve agricultural production.

The Polish countryside occupies more than 93\% of the surface area of our country [SOBOLEWSKA-MiKULSKA 2015]. About 3 million hectares of agricultural land in Poland are characterised by a faulty pattern of land ownership. The land ownership patchwork is one of the key factors that have a negative impact on the organization and level of agricultural production. Fields in a patchwork may be located either in the same village where the owners live 
or outside this area. In most cases, this unfavourable situation is a result of migration of rural residents to larger towns and cities which are administrative, industrial and cultural-educational centres as well as important sources of employment. Non-resident owners are mostly people who have inherited farmland from their parents, or, less frequently, people who have migrated to cities. There is also a group of non-resident owners who have no family connection with the village in which they own land, but who have bought a plot in a rural area for building purposes because they found the localization of the plots attractive or appreciated the low prices of such plots [LEŃ 2012]. This state of affairs has led to a situation in which a large part of land is fallowed or used in an informal way.

Measures should be taken to eliminate both internal and external patchworks of farmland. Two such agricultural land management land consolidation and land exchange are measured. Rural areas in Poland are in need of profound structural changes related to agricultural production, the size of agricultural holdings, the distribution of farmland in an agricultural holding, as well as the demographic, spatial and institutional structure of those areas [SOBOLEWSKA-MIKULSKA 2009; SOBOLEWSKA-MIKULSKA, WÓJCIK 2012; WÓJCIK 2012]. Consolidation and exchange of land can not only improve a farmer's living and working conditions, but also contribute to enhancing the environmental and cultural assets of a village. Agricultural land management interventions can play an important role in the protection of landscape and the environment, development of rural areas and agriculture, as well as preservation of traditions and cultural heritage. The economic and environmental benefits of agricultural land management are indisputable [NoGA, KRÓL 2016].

Previous studies have demonstrated that land located in an external patchwork of fields is a very large problem in rural areas in central Poland. An analysis carried out in the villages of the commune of Sławno (district of Opoczno, Łódź Province) showed that $40.9 \%$ of the total surface area of farmland belonging to individual holdings was located in external patchworks, which represented $43.1 \%$ of the total number of privately owned plots [LEŃ, MIKA 2016a]. A preliminary study in the village of Brzustowiec, located in the commune of Drzewica showed that $26.9 \%$ of the total number of privately owned plots of land (23.8\% of all private farmland) in that village belonged to out-of-village owners [LEŃ, MIKA 2016b].

The fragmentary results obtained for the commune of Drzewica became an incentive for further studies of this area. The aim of the present article was to determine the degree of fragmentation of farmland in the villages of the commune of Drzewica using checkerboard tables and to discuss the possibilities of eliminating this problem.

\section{MATERIALS AND METHODS}

Fragmentation studies were carried out in 17 villages of the commune of Drzewica, located in the district of Opoczno. A map showing the geographical situation of the commune of Drzewica is presented in Figure 1.

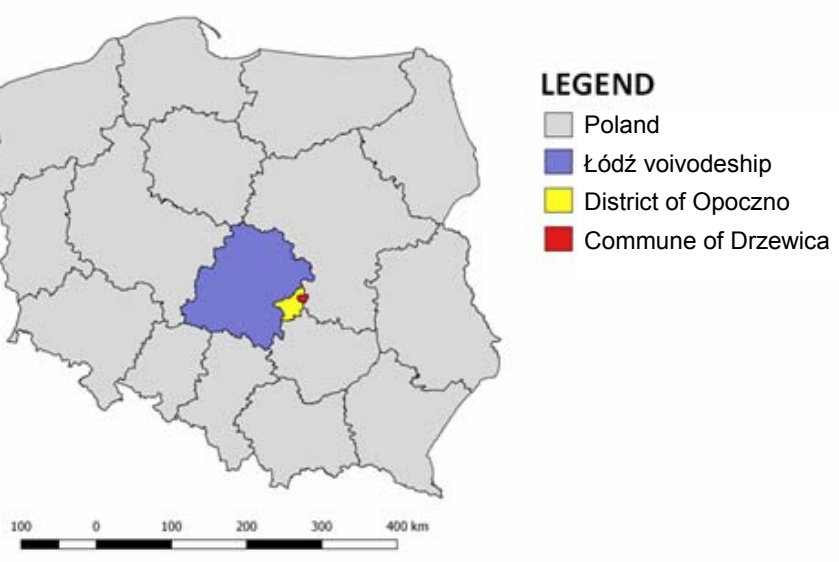

Fig. 1. The geographical situation of the commune of Drzewica on the map of Poland; source: own elaboration

As data in Table 1 show, the total number of outof-village non-resident owners in the commune of Drzewica is 2587 persons. These owners possess a total of 8993 parcels occupying a surface area of 2813.09 ha, i.e. $31.1 \%$ of the total area of the commune. The average area of a plot is $0.31 \mathrm{ha}$, and the average plot area per owner is 1.09 ha.

The study of the number of plots owned by outof-village non-resident owners shows that in Radzice Małe, 2,589 parcels are owned by 431 people who are not inhabitants of the village; these plots represent $58.9 \%$ of the total number of plots in the private sector in the commune of Drzewica. Their total area is 642.11 ha, ie. $49.6 \%$ of the total surface area of privately owned land. It is worth noting that such a high percentage of land belonging to out-of-village owners presents a barrier to undertaking any attempts at land consolidation, because in such a situation it is impossible to collect the declarations of over $50.0 \%$ of landowners required for making a decision on consolidation and exchange of land.

The data presented in Table 2 show that in the commune of Drzewica, 3,358 plots, out of the total of 25,531 parcels belonging to 896 owners, are owned by local non-residents. This corresponds to an area equal to 907.87 hectares, which constitutes $10.0 \%$ of the total area of the commune.

The greatest number of plots belonging to local non-residents was recorded for the village of Radzice Duże. The study shows that 972 plots in that locality belong to this group of owners, representing $67.2 \%$ of all parcels in the private sector. The total surface area of these plots is 240.68 ha $(33.9 \%$ of the surface area of privately owned land). The smallest number of 
Table 1. Farmland belonging to out-of-village non-resident owners in the commune of Drzewica

\begin{tabular}{|c|c|c|c|c|c|c|c|c|c|}
\hline \multirow{3}{*}{$\begin{array}{l}\text { Name } \\
\text { of village }\end{array}$} & \multirow{3}{*}{$\begin{array}{c}\text { Surface area of } \\
\text { privately owned } \\
\text { farmland }\end{array}$} & \multirow{3}{*}{$\begin{array}{c}\text { Number of } \\
\text { privately } \\
\text { owned plots }\end{array}$} & \multicolumn{7}{|c|}{ Farmland belonging to out-of-village owners } \\
\hline & & & \multirow{2}{*}{$\begin{array}{l}\text { owners } \\
\text { number }\end{array}$} & \multicolumn{2}{|c|}{ plots } & \multirow{2}{*}{$\begin{array}{l}\text { mean surface } \\
\text { area of a plot }\end{array}$} & \multicolumn{2}{|c|}{ surface area } & \multirow{2}{*}{$\begin{array}{l}\text { mean surface area } \\
\text { of a plot per owner }\end{array}$} \\
\hline & & & & number & $\%$ & & ha & $\%$ & \\
\hline Brzustowiec & 610.49 & 1909 & 153 & 423 & 22.2 & 0,30 & 128.15 & 21.0 & 0.84 \\
\hline Brzuza & 284.05 & 1199 & 87 & 398 & 33.2 & 0,22 & 86.71 & 30.5 & 1.00 \\
\hline Dąbrówka & 469.63 & 1060 & 171 & 356 & 33.6 & 0,38 & 135.51 & 28.9 & 0.79 \\
\hline Domaszno & 965.07 & 2095 & 83 & 411 & 19.6 & 0,40 & 163.13 & 16.9 & 1.97 \\
\hline Giełzów & 324.68 & 866 & 90 & 351 & 40.5 & 0,34 & 119.16 & 36.7 & 1.32 \\
\hline Idzikowice & 735.96 & 2170 & 194 & 798 & 36.8 & 0,31 & 249.92 & 34.0 & 1.29 \\
\hline Jelnia & 500.18 & 1026 & 166 & 349 & 34.0 & 0,44 & 154.78 & 30.9 & 0.93 \\
\hline Krzczonów & 782.21 & 2127 & 159 & 543 & 25.5 & 0,40 & 216.63 & 27.7 & 1.36 \\
\hline Radzice Duże & 709.33 & 1446 & 137 & 499 & 34.5 & 0,37 & 183.72 & 25.9 & 1.34 \\
\hline Radzice Małe & 1293.65 & 4392 & 431 & 2589 & 58.9 & 0,25 & 642.11 & 49.6 & 1.49 \\
\hline Strzyżów & 144.14 & 844 & 67 & 148 & 17.5 & 0,19 & 27.87 & 19.3 & 0.42 \\
\hline Świerczyna & 259.73 & 510 & 48 & 110 & 21.6 & 0,54 & 59.86 & 23.0 & 1.25 \\
\hline Trzebina & 542.72 & 1076 & 141 & 292 & 27.1 & 0,51 & 147.62 & 27.2 & 1.05 \\
\hline Werówka & 340.92 & 1283 & 136 & 422 & 32.9 & 0,23 & 95.41 & 28.0 & 0.70 \\
\hline Zakościele & 435.83 & 1998 & 295 & 675 & 33.8 & 0,28 & 191.61 & 44.0 & 0.65 \\
\hline Żardki & 422.43 & 1037 & 116 & 405 & 39.1 & 0,30 & 123.36 & 29.2 & 1.06 \\
\hline Żdżary & 225.88 & 493 & 91 & 224 & 45.4 & 0,39 & 87.54 & 38.8 & 0.96 \\
\hline Total & 9046.90 & 25531 & 2587 & 8993 & 35.2 & 0,31 & 2813.09 & 31.1 & 1.09 \\
\hline
\end{tabular}

Source: own elaboration.

Table 2. Farmland belonging to local non-resident owners in the villages of the commune of Drzewica

\begin{tabular}{|c|c|c|c|c|c|c|c|}
\hline \multirow{3}{*}{$\begin{array}{l}\text { Name } \\
\text { of village }\end{array}$} & \multicolumn{7}{|c|}{ Farmland belonging to local non-resident owners } \\
\hline & \multirow{2}{*}{$\begin{array}{c}\text { owners } \\
\text { number }\end{array}$} & \multicolumn{2}{|c|}{ plots } & \multirow{2}{*}{$\begin{array}{c}\text { mean surface area } \\
\text { of a plot }\end{array}$} & \multicolumn{2}{|c|}{ surface area } & \multirow{2}{*}{$\begin{array}{l}\text { mean surface area } \\
\text { of a plot per owner }\end{array}$} \\
\hline & & number & $\%$ & & ha & $\%$ & \\
\hline Brzustowiec & 39 & 113 & 5.9 & 0.33 & 37.65 & 6.2 & 0.97 \\
\hline Brzuza & 102 & 391 & 32.6 & 0.26 & 102.13 & 36.0 & 1.00 \\
\hline Dąbrówka & 33 & 121 & 11.4 & 0.21 & 25.03 & 5.3 & 0.76 \\
\hline Domaszno & 44 & 119 & 5.7 & 0.31 & 37.71 & 3.9 & 0.86 \\
\hline Giełzów & 26 & 89 & 10.3 & 0.28 & 25.42 & 7.8 & 0.98 \\
\hline Idzikowice & 51 & 197 & 9.1 & 0.19 & 37.47 & 5.1 & 0.73 \\
\hline Jelnia & 75 & 150 & 14.6 & 0.31 & 47.31 & 9.5 & 0.63 \\
\hline Krzczonów & 21 & 34 & 1.6 & 0.31 & 10.57 & 1.4 & 0.50 \\
\hline Radzice Duże & 163 & 972 & 67.2 & 0.24 & 240.68 & 33.9 & 1.48 \\
\hline Radzice Małe & 42 & 157 & 3.6 & 0.25 & 39.99 & 3.1 & 0.95 \\
\hline Strzyżów & 61 & 228 & 27.0 & 0.20 & 46.72 & 32.4 & 0.77 \\
\hline Świerczyna & 40 & 86 & 16.9 & 0.42 & 36.3 & 14.0 & 0.91 \\
\hline Trzebina & 30 & 82 & 7.6 & 0.43 & 35.84 & 6.6 & 1.19 \\
\hline Werówka & 59 & 171 & 13.3 & 0.29 & 50.55 & 14.8 & 0.86 \\
\hline Zakościele & 71 & 158 & 7.9 & 0.19 & 30.13 & 6.9 & 0.42 \\
\hline Żardki & 24 & 237 & 22.9 & 0.37 & 89.26 & 21.1 & 3.72 \\
\hline Żdżary & 15 & 53 & 10.8 & 0.28 & 15.04 & 6.7 & 1.00 \\
\hline Total & 896 & 3358 & 13.2 & 0.27 & 907.87 & 10.0 & 1.01 \\
\hline
\end{tabular}

Source: own elaboration.

plots belonging to local non-residents was found in the village of Krzczonów. Twenty one owners own 34 cadastral plots there (1.6\% of group 7 plots), with a total surface area of 10.57 ha $(1.4 \%$ of the surface area of privately owned land).

The research showed that a very important factor affecting the size of land owned by out-of village nonresidents is the location of the commune of Drzewica. It is situated in central Poland, in close proximity to the district town of Opoczno $(20 \mathrm{~km})$, the capital of the province, Łódź $(90 \mathrm{~km})$, and the capital of the country, Warsaw $(100 \mathrm{~km})$. The range of non-resident land ownership is much broader, because many inhabitants of the investigated area have found em- ployment in other towns and cities of the Łódź Province and neighbouring provinces.

Detailed studies of land ownership by out-of village non-residents from the town of Drzewica, which is the seat of commune authorities and the major cultural centre, showed (Tab. 3) that 360 inhabitants of this town are proprietors of 978 cadastral plots with a total area of 295.60 hectares, representing $3.3 \%$ of the total surface area of private farm holdings. The analyses showed that the majority of plots in the hands of the inhabitants of Drzewica are located in villages directly adjacent to this town (Zakościele, Dąbrówka, Brzustowiec, Jelnia, Strzyżów) and in the largest village in the commune (Radzice Małe). 
Table 3. Farmland belonging to out-of-village non-resident owners from the town of Drzewica

\begin{tabular}{|c|c|c|c|c|c|c|c|}
\hline \multirow{3}{*}{$\begin{array}{c}\text { Name } \\
\text { of village }\end{array}$} & \multicolumn{7}{|c|}{ Farmland belonging to out-of-village owners } \\
\hline & \multirow{2}{*}{$\begin{array}{l}\text { owners } \\
\text { number }\end{array}$} & \multicolumn{2}{|c|}{ plots } & \multirow{2}{*}{$\begin{array}{c}\text { mean surface area } \\
\text { of a plot }\end{array}$} & \multicolumn{2}{|c|}{ surface area } & \multirow{2}{*}{$\begin{array}{l}\text { mean surface area } \\
\text { of a plot per owner }\end{array}$} \\
\hline & & number & $\%$ & & ha & $\%$ & \\
\hline Brzustowiec & 60 & 144 & 7.5 & 0.25 & 35.94 & 5.9 & 0.60 \\
\hline Brzuza & 1 & 6 & 0.5 & 0.37 & 2.19 & 0.8 & 2.19 \\
\hline Dąbrówka & 64 & 120 & 11.3 & 0.36 & 42.72 & 9.1 & 0.67 \\
\hline Domaszno & 13 & 38 & 1.8 & 0.45 & 17.13 & 1.8 & 1.32 \\
\hline Giełzów & 5 & 5 & 0.6 & 0.81 & 4.07 & 1.3 & 0.81 \\
\hline Idzikowice & 0 & 0 & 0.0 & 0.00 & 0.00 & 0.0 & 0.00 \\
\hline Jelnia & 31 & 62 & 6.0 & 0.47 & 29.27 & 5.9 & 0.94 \\
\hline Krzczonów & 9 & 17 & 0.8 & 0.47 & 7.96 & 1.0 & 0.88 \\
\hline Radzice Duże & 12 & 81 & 5.6 & 0.29 & 23.46 & 3.3 & 1.95 \\
\hline Radzice Małe & 16 & 137 & 3.1 & 0.24 & 32.30 & 2.5 & 2.02 \\
\hline Strzyżów & 18 & 41 & 4.9 & 0.20 & 8.11 & 5.6 & 0.45 \\
\hline Świerczyna & 1 & 1 & 0.2 & 1.06 & 1.06 & 0.4 & 1.06 \\
\hline Trzebina & 1 & 2 & 0.2 & 0.08 & 0.15 & 0.0 & 0.15 \\
\hline Werówka & 11 & 28 & 2.2 & 0.22 & 6.28 & 1.8 & 0.57 \\
\hline Zakościele & 98 & 208 & 10.4 & 0.30 & 63.35 & 14.5 & 0.65 \\
\hline Żardki & 11 & 35 & 3.4 & 0.25 & 8.76 & 2.1 & 0.80 \\
\hline Żdżary & 9 & 53 & 10.8 & 0.24 & 12.87 & 5.7 & 1.43 \\
\hline Total & 360 & 978 & 3.8 & 0.30 & 295.60 & 3.3 & 0.82 \\
\hline
\end{tabular}

Source: own elaboration.

287 owners from the town of Drzewica own land in these 6 villages $(79.7 \%$ of the total number of nonresident owners). They are proprietors of 712 plots (72.7\% of the total number of plots) with a surface area of 211.68 ha $(71.6 \%$ of the total surface area of land belonging to out-of-village owners residing in Drzewica).

Detailed studies of land ownership by out-of village non-residents from the district town of Opoczno showed (Tab. 4) that 144 inhabitants of Opoczno own 542 cadastral plots in 15 villages of the commune of Drzewica. These plots occupy an area of 198.30 ha, which constitutes $2.2 \%$ of privately owned land. The largest number of plots belonging to out-of-village non-resident owners from the district town are located in the village Radzice Małe, where 19 owners have 122 plots with a total area of 38.43 ha. In the village of Krzczonów, 21 inhabitants of Opoczno own 75 cadastral plots occupying a total area of 35.99 ha. In the villages of Idzikowice, Giełzów and Radzice Duże owners from Opoczno are in the possession of a considerable percentage of privately owned land.

Another important urban centre whose inhabitants own land in the commune of Drzewica is the capital of the province, Łódź. Located at a distance of approx. $90 \mathrm{~km}$ from the commune, it still exerts an important impact on out-of-village ownership of farmland in Drzewica. The results of a study conducted for the city of Łódź are presented in Table 5.

Table 4. Farmland belonging to out-of-village non-resident owners from the town of Opoczno

\begin{tabular}{|c|c|c|c|c|c|c|c|}
\hline \multirow{3}{*}{$\begin{array}{c}\text { Name } \\
\text { of village }\end{array}$} & \multicolumn{7}{|c|}{ Farmland belonging to out-of-village owners } \\
\hline & \multirow{2}{*}{$\begin{array}{c}\text { owners } \\
\text { number }\end{array}$} & \multicolumn{2}{|c|}{ plots } & \multirow{2}{*}{$\begin{array}{c}\text { mean surface area } \\
\text { of a plot }\end{array}$} & \multicolumn{2}{|c|}{ surface area } & \multirow{2}{*}{$\begin{array}{l}\text { mean surface area } \\
\text { of a plot per owner }\end{array}$} \\
\hline & & number & $\%$ & & ha & $\%$ & \\
\hline Brzustowiec & 7 & 25 & 1.3 & 0.21 & 5.47 & 0.9 & 0.78 \\
\hline Brzuza & 5 & 20 & 1.7 & 0.21 & 4.27 & 1.5 & 0.85 \\
\hline Dąbrówka & 5 & 6 & 0.6 & 0.4 & 2.45 & 0.5 & 0.49 \\
\hline Domaszno & 0 & 0 & 0.0 & 0.00 & 0.00 & 0.0 & 0.00 \\
\hline Giełzów & 12 & 64 & 7.4 & 0.23 & 15.29 & 4.7 & 1.27 \\
\hline Idzikowice & 19 & 78 & 3.6 & 0.45 & 35.36 & 4.8 & 1.86 \\
\hline Jelnia & 9 & 30 & 2.9 & 0.58 & 17.55 & 3.5 & 1.95 \\
\hline Krzczonów & 21 & 75 & 3.5 & 0.47 & 35.99 & 4.6 & 1.71 \\
\hline Radzice Duże & 12 & 39 & 2.7 & 0.50 & 19.53 & 2.8 & 1.63 \\
\hline Radzice Małe & 19 & 122 & 2.8 & 0.31 & 38.43 & 3.0 & 2.02 \\
\hline Strzyżów & 8 & 13 & 1.5 & 0.11 & 1.54 & 1.1 & 0.19 \\
\hline Świerczyna & 4 & 8 & 1.6 & 0.36 & 2.91 & 1.1 & 0.73 \\
\hline Trzebina & 9 & 31 & 2.9 & 0.37 & 11.73 & 2.2 & 1.30 \\
\hline Werówka & 6 & 14 & 1.1 & 0.26 & 3.73 & 1.1 & 0.62 \\
\hline Zakościele & 7 & 13 & 0.7 & 0.19 & 2.56 & 0.6 & 0.37 \\
\hline Żardki & 1 & 4 & 0.4 & 0.37 & 1.50 & 0.4 & 1.50 \\
\hline Żdżary & 0 & 0 & 0.0 & 0.00 & 0.00 & 0.0 & 0.00 \\
\hline Razem & 144 & 542 & 2.1 & 0.36 & 198.30 & 2.2 & 1.38 \\
\hline
\end{tabular}

Source: own elaboration. 
Table 5. Farmland belonging to out-of-village non-resident owners from the city of Łódź

\begin{tabular}{|c|c|c|c|c|c|c|c|}
\hline \multirow{3}{*}{$\begin{array}{c}\text { Name } \\
\text { of village }\end{array}$} & \multicolumn{7}{|c|}{ Farmland belonging to out-of-village owners } \\
\hline & \multirow{2}{*}{$\begin{array}{l}\text { owners } \\
\text { number }\end{array}$} & \multicolumn{2}{|c|}{ plots } & \multirow{2}{*}{$\begin{array}{c}\text { mean surface area } \\
\text { of a plot }\end{array}$} & \multicolumn{2}{|c|}{ surface area } & \multirow{2}{*}{$\begin{array}{l}\text { mean surface area } \\
\text { of a plot per owner }\end{array}$} \\
\hline & & number & $\%$ & & ha & $\%$ & \\
\hline Brzustowiec & 7 & 55 & 2.9 & 0.11 & 6.37 & 1.0 & 0.91 \\
\hline Brzuza & 1 & 1 & 0.1 & 0.19 & 0.19 & 0.1 & 0.19 \\
\hline Dąbrówka & 10 & 16 & 1.5 & 0.46 & 7.40 & 1.6 & 0.74 \\
\hline Domaszno & 9 & 47 & 2.2 & 0.35 & 16.83 & 1.7 & 1.87 \\
\hline Giełzów & 4 & 13 & 1.5 & 0.41 & 5.42 & 1.7 & 1.36 \\
\hline Idzikowice & 3 & 18 & 0.8 & 0.32 & 5.75 & 0.8 & 1.92 \\
\hline Jelnia & 3 & 7 & 0.7 & 0.23 & 1.66 & 0.3 & 0.55 \\
\hline Krzczonów & 6 & 17 & 0.8 & 0.19 & 3.33 & 0.4 & 0.56 \\
\hline Radzice Duże & 9 & 24 & 1.7 & 0.47 & 11.37 & 1.6 & 1.26 \\
\hline Radzice Małe & 11 & 38 & 0.9 & 0.25 & 9.72 & 0.8 & 0.88 \\
\hline Strzyżów & 2 & 4 & 0.5 & 0.17 & 0.71 & 0.5 & 0.36 \\
\hline Świerczyna & 0 & 0 & 0.0 & 0.00 & 0.00 & 0.0 & 0.00 \\
\hline Trzebina & 4 & 7 & 0.7 & 0.40 & 2.80 & 0.5 & 0.70 \\
\hline Werówka & 2 & 2 & 0.2 & 0.25 & 0.50 & 0.2 & 0.25 \\
\hline Zakościele & 16 & 57 & 2.9 & 0.15 & 8.61 & 2.0 & 0.54 \\
\hline Żardki & 4 & 26 & 2.5 & 0.26 & 6.76 & 1.6 & 1.69 \\
\hline Żdżary & 3 & 4 & 0.8 & 0.55 & 2.20 & 1.0 & 0.73 \\
\hline Razem & 94 & 336 & 1.3 & 0.27 & 89.69 & 1.0 & 0.95 \\
\hline
\end{tabular}

Source: own elaboration.

As is clear from the study, 94 inhabitants of Łódź own 336 plots in Drzewica with a total area of 89.69 ha, which represents $1.0 \%$ of the total area of the commune. The largest numbers of owners from Łódź were recorded in the villages of Zakościele (16 people), Radzice Małe (11) Dąbrówka (10), Domaszno and Radzice Duże (9 owners each). The numbers of plots and their surface areas were different for the different localities: Zakościele - 57 plots, 8.61 ha; Brzustowiec - 55 plots, 6.37 ha; Domaszno - 47 plots, 16.83 ha); Radzice Małe - 38 plots, 9.72 ha; Żardki - 26 plots, 6.76 ha; Radzice Duże - 24 plots, 11.37 ha. In the villages of Idzikowice, Krzczonów, Dąbrówka and Giełzów, the share of farmland in the hands of out-of-village owners from the city of Łódź was much smaller, and in the remaining villages of the commune, it was negligible.

The last of the cities analysed for their effect on the share of farmland belonging to out-of-village owners was the Polish capital, Warsaw. Despite the $100 \mathrm{~km}$ distance of the capital from the area studied, some farmland in the villages of the commune of Drzewica is owned by inhabitants of Warsaw, as shown in Table 6.

As evident from the analyses, 65 out-of-village owners from Warsaw are in the possession of 180 cadastral plots in 14 villages of the commune of Drzewica. The total surface area of these plots is 71.94 ha, i.e. $0.8 \%$ of the total surface area of the commune. The largest number of cadastral plots (29)

Table 6. Farmland belonging to out-of-village non-resident owners from the capital city of Warsaw

\begin{tabular}{|c|c|c|c|c|c|c|c|}
\hline \multirow{3}{*}{$\begin{array}{c}\text { Name } \\
\text { of village }\end{array}$} & \multicolumn{7}{|c|}{ Farmland belonging to out-of-village owners } \\
\hline & \multirow{2}{*}{$\begin{array}{l}\text { owners } \\
\text { number }\end{array}$} & \multicolumn{2}{|c|}{ plots } & \multirow{2}{*}{$\begin{array}{c}\text { mean surface area } \\
\text { of a plot }\end{array}$} & \multicolumn{2}{|c|}{ surface area } & \multirow{2}{*}{$\begin{array}{l}\text { mean surface area } \\
\text { of a plot per owner }\end{array}$} \\
\hline & & number & $\%$ & & ha & $\%$ & \\
\hline Brzustowiec & 5 & 13 & 0.7 & 0.41 & 5.41 & 0.9 & 1.08 \\
\hline Brzuza & 2 & 13 & 1.1 & 0.21 & 2.83 & 1.0 & 1.41 \\
\hline Dąbrówka & 8 & 29 & 2.7 & 0.41 & 11.90 & 2.5 & 1.48 \\
\hline Domaszno & 4 & 12 & 0.6 & 0.52 & 6.28 & 0.7 & 1.57 \\
\hline Giełzów & 0 & 0 & 0.0 & 0.00 & 0.00 & 0.0 & 0.00 \\
\hline Idzikowice & 7 & 20 & 0.9 & 0.30 & 6.07 & 0.8 & 0.86 \\
\hline Jelnia & 4 & 6 & 0.6 & 0.95 & 5.72 & 1.2 & 1.43 \\
\hline Krzczonów & 4 & 10 & 0.5 & 0.46 & 4.64 & 0.6 & 1.16 \\
\hline Radzice Duże & 8 & 21 & 1.5 & 0.34 & 7.32 & 1.0 & 0.91 \\
\hline Radzice Małe & 5 & 16 & 0.4 & 0.37 & 5.95 & 0.5 & 1.19 \\
\hline Strzyżów & 0 & 0 & 0.0 & 0.00 & 0.00 & 0.0 & 0.00 \\
\hline Świerczyna & 0 & 0 & 0.0 & 0.00 & 0.00 & 0.0 & 0.00 \\
\hline Trzebina & 3 & 4 & 0.4 & 0.60 & 2.40 & 0.4 & 0.80 \\
\hline Werówka & 2 & 2 & 0.2 & 1.34 & 2.69 & 0.8 & 1.34 \\
\hline Zakościele & 8 & 17 & 0.9 & 0.20 & 3.50 & 0.8 & 0.43 \\
\hline Żardki & 4 & 15 & 1.5 & 0.45 & 6.84 & 1.6 & 1.71 \\
\hline Żdżary & 1 & 2 & 0.4 & 0.17 & 0.34 & 0.2 & 0.34 \\
\hline Razem & 65 & 180 & 0.7 & 0.39 & 71.94 & 0.8 & 1.10 \\
\hline
\end{tabular}

Source: own elaboration. 
with a total area of 11.90 ha belonging to 8 owners are located in the village of Dąbrówka. In the village of Radzice Duże, 8 owners have 21 plots occupying an area of 7.32 ha. In the village of Zakościele, 8 inhabitants of Warsaw own 17 plots with a total area of 3.50 ha. In the village of Idzikowice 7 owners from the capital city have 20 plots with an area of 6.07 ha. The figures for the remaining villages are as follows: Brzustowiec (5 owners, 13 plots, 5.41 ha), Radzice Małe (5 owners, 16 plots, 5.95 ha), Domaszno (4 owners, 12 plots, 6.28 ha). In other villages, the share of farmland belonging to owners from Warsaw is small.

\section{RESULTS AND DISCUSSION}

The use of checkerboard tables [NoGA 1985] in the analysis and assessment of a checkerboard (patchwork) pattern of land ownership allows one to create a matrix of any degree for one or several villages or an entire commune, depending on the territorial scope of the patchwork of fields. The resultant matrix is ordered so that the highest values are situated along the diagonal, which allows one to identify areas of the greatest concentration of checkerboarded farmland. An ordered matrix makes it possible to determine not only the above-mentioned regularities but also the degree of fragmentation and scope of the patchwork of fields, both between villages and subsets of villages, but also for an entire commune By using this method for studying, balancing and analysing a patchwork of fields, one can establish, in a clear and simple way, the degree of fragmentation of land belonging to agricultural holdings [NoGA 2001]. Detailed data are given in Table 7, and a spatial image of the clustering of villages is shown in Figure 2.
The method of checkerboard tables used in this study helped us to establish in a clear way the degree of fragmentation of land in the villages of the studied commune. On the basis of the obtained matrix, we can determine precisely the surface area of plots of land which could be brought closer together or for which an exchange programme could be developed (Tab. 7). As the results show, there are regularities concerning the clustering of villages situated in the immediate

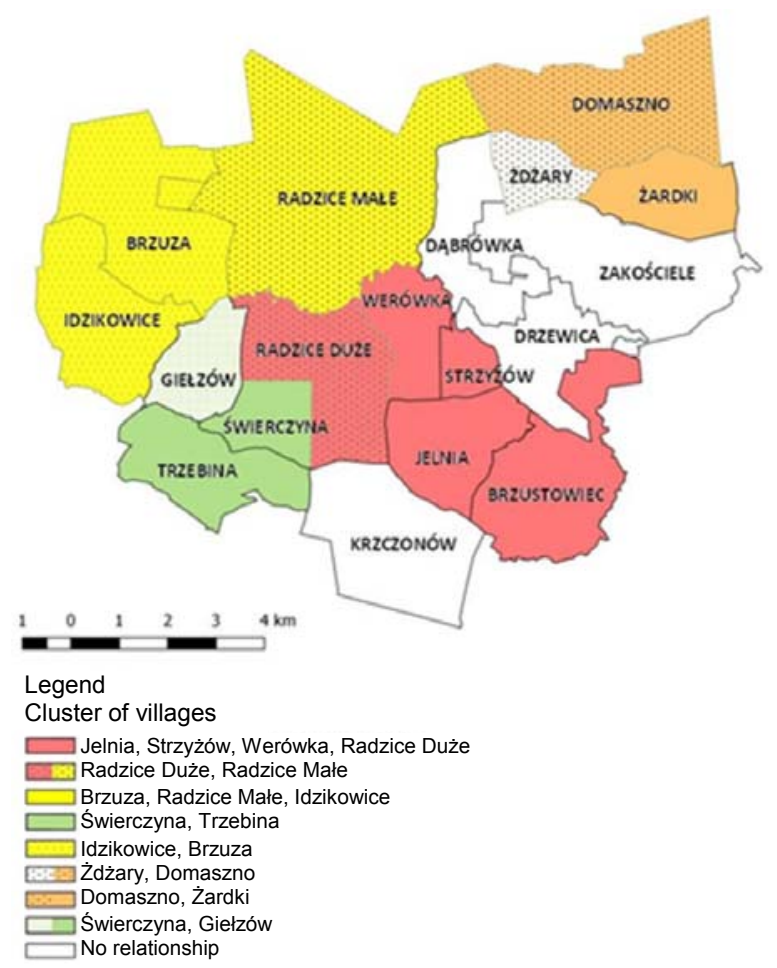

Fig. 2. A map of clustering of villages in the commune of Drzewica; source: own elaboration

Table 7. Matrix of the patchwork of farmland in the commune of Drzewica

\begin{tabular}{|c|c|c|c|c|c|c|c|c|c|c|c|c|c|c|c|c|c|}
\hline $\begin{array}{l}\text { Villages where } \\
\text { non-resident } \\
\text { owners live }\end{array}$ & 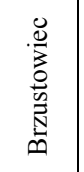 & 丞 & 亭 & $\begin{array}{l}\frac{\tilde{4}}{3} \\
\frac{0}{0} \\
3 \\
3\end{array}$ & 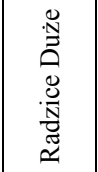 & 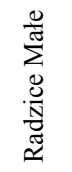 & 苂 & 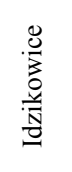 & \begin{tabular}{l}
$\stackrel{\Xi}{0}$ \\
$\stackrel{0}{0}$ \\
\multirow{N}{*}{}
\end{tabular} & 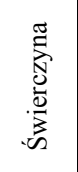 & 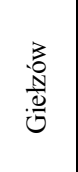 & $\begin{array}{l}3 \\
0 \\
0 \\
N \\
N \\
N\end{array}$ & $\begin{array}{l}\vec{y} \\
\text { ज्ञ } \\
\text { N }\end{array}$ & 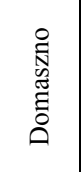 & 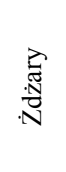 & 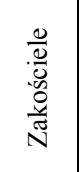 & 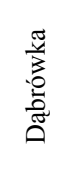 \\
\hline Brzustowiec & $\times$ & 8.16 & 2.60 & 0.53 & 3.48 & 2.91 & - & - & - & - & - & 0.19 & 2.69 & 0.34 & - & 1.75 & - \\
\hline Jelnia & 10.10 & $x$ & 6.19 & 2.11 & 4.66 & 3.42 & - & - & 0.58 & - & 0.22 & 0.84 & - & 3.02 & - & 0.66 & - \\
\hline Strzyżów & 0.04 & 3.03 & $x$ & 4.73 & 0.28 & - & - & - & - & - & - & 0.00 & - & - & - & - & - \\
\hline Werówka & 0.50 & 6.67 & 18.33 & $x$ & 10.44 & 1.58 & 1.52 & - & - & - & - & 0.19 & - & - & 0.20 & 0.74 & 0.36 \\
\hline Radzice Duże & 0.48 & 9.83 & 0.98 & 8.55 & $x$ & 13.17 & 3.01 & 2.94 & 1.70 & 9.74 & 0.81 & - & - & - & 0.42 & - & 1.07 \\
\hline Radzice Małe & 1.37 & 3.15 & 13.64 & 14.04 & 194.61 & $\times$ & 36.78 & 4.04 & 1.32 & - & 12.28 & 0.26 & 1.20 & - & 0.57 & 3.52 & 19.66 \\
\hline Brzuza & - & 0.40 & - & - & 1.58 & 1.78 & $\times$ & 23.99 & - & 0.29 & 0.28 & - & - & - & - & - & - \\
\hline Idzikowice & - & - & - & - & 0.96 & 2.12 & 43.85 & $\times$ & 0.91 & 0.76 & 0.63 & - & - & - & - & - & - \\
\hline Trzebina & 2.17 & - & - & 0.81 & 0.87 & 0.89 & - & 1.81 & $\times$ & 22.27 & 2.73 & 2.50 & 0.58 & - & - & - & - \\
\hline Świerczyna & - & - & - & 0.35 & 5.63 & 3.72 & 1.56 & - & 13.58 & $x$ & 7.05 & - & - & - & - & - & 1.05 \\
\hline Giełżów & - & - & 1.38 & 2.02 & 8.07 & 0.18 & 15.42 & 4.29 & 8.02 & 2.91 & $x$ & 0.66 & - & - & - & - & - \\
\hline Krzczonów & 19.28 & 13.73 & - & - & 1.59 & 3.02 & - & - & 9.73 & 0.33 & 0.97 & $x$ & 2.04 & - & - & - & - \\
\hline Żardki & - & - & 0.39 & 2.69 & 0.53 & 0.29 & - & - & - & - & - & 1.26 & $x$ & 17.39 & 6.53 & 8.41 & 1.51 \\
\hline Domaszno & 2.72 & 1.23 & 0.70 & - & 4.08 & - & - & - & $\begin{array}{llll}- & \\
\end{array}$ & $\begin{array}{llll}- & \\
\end{array}$ & - & 0.21 & 9.29 & $\times$ & 6.33 & 0.47 & 1.36 \\
\hline Żdżary & - & - & - & - & - & $\begin{array}{lll}- & \\
\end{array}$ & $\begin{array}{lll}- & \\
\end{array}$ & - & $\begin{array}{lll}- & \\
\end{array}$ & $\begin{array}{ll}- & \\
\end{array}$ & $\begin{array}{lll}- & \\
\end{array}$ & 1.00 & 20.47 & \begin{tabular}{|l|}
14.26 \\
\end{tabular} & $x$ & 12.49 & - \\
\hline Zakościele & 0.10 & 0.71 & 1.07 & 0.52 & 1.42 & - & - & - & - & - & - & 0.49 & 53.00 & 2.71 & 0.99 & $\times$ & 0.03 \\
\hline Dąbrówka & 0.89 & 0.39 & 1.45 & 14.21 & 2.49 & 6.91 & - & 0.40 & - & - & 0.45 & 2.98 & - & - & - & 2.10 & $x$ \\
\hline
\end{tabular}

Source: own elaboration. 
vicinity of one another. Such relationships were found among the villages of Jelnia, Strzyżów, Werówka and Radzice Duże. Large dependencies regarding the cadastral surface area were also found between the villages of Radzice Duże and Radzice Małe, as well as between Świerczyna - Giełzów and Świerczyna Trzebinia. In the north-eastern part of the commune, relationships obtained between the villages of Domaszno - Żdżary and Domaszno - Żardki.

Considering the fact that the external patchwork of land in Drzewica which requires consolidation is so large, the inhabitants of the commune should first be offered a land exchange programme, as it is difficult to cover the entire area of the commune with a consolidation programme. Such a programme will allow to bring farmland belonging to owners from other villages of the commune closer to their farm homesteads.

\section{CONCLUSIONS}

The investigations of the external patchwork of farmland in the villages of the commune of Drzewica revealed serious defects in the pattern of land ownership. The analysis showed that 2,587 owners were in the possession of 8,993 cadastral plots, which constituted $35.2 \%$ of the total number of privately owned plots in the commune. These plots occupied an area of $2,813.09$ ha, i.e. $31.1 \%$ of the total surface area of farmland belonging to individual holdings. The whole situation was exacerbated by the fact that as many as 3,358 plots $(13.2 \%$ of privately owned plots) belonged to local non-resident owners. They occupied a surface area of 907.87 ha, which represented $10.04 \%$ of privately owned farmland.

The study also showed that farmland owners from towns and cities had a significant share in nonresident owned farmland. 360 owners from the town of Drzewica, which is the seat of the commune authorities and the main cultural centre of the commune, were in the possession of 978 cadastral plots, with a total area of 295.60 ha, i.e. $3.3 \%$ of the total surface area of farmland belonging to individual holdings. 144 owners of 542 cadastral plots ( 198.30 ha, $2.2 \%$ of the surface area of the commune) lived in the district town of Opoczno. 94 owners of 336 cadastral plots ( 89.69 ha, $1.0 \%$ of privately owned land in the commune) lived in Łódź. 180 cadastral plots with an area of 71.94 hectares, i.e. $0.8 \%$ of the total surface area of the commune belonged to inhabitants of Warsaw. The fact that residents of towns and cities own land in the villages of the commune of Drzewica is due to the migration of rural people to urban areas and inheritance of land. Another factor is the financial benefits offered by urban centres and their large labour market as well as the fact that young people move to cities to study at higher education institutions. However, this can work the other way, too. City dwellers buy plots in rural areas to settle there in the future or for recreational purposes. The favourable conditions for tourist activities and the good location of the commune in terms of access from towns and cities encourage inhabitants of cities to buy attractive recreational plots there.

Particularly noteworthy is ownership of plots by city-dwellers. A detailed study should be carried out regarding the surface area of these plots of land and their current use (recreational plots, building plots, plots not used for agricultural purposes, plots informally used for agricultural purposes). These plots of land, if unused, could be leased to local farmers. Regulations related to land lease are provided in Articles 693-709 of the Civil Code [Ustawa... 1964] and the Act of 5 August 2015 on the Structuring of the Agricultural System [Ustawa... 2015]. As of 2016, lease contracts not concluded in writing are deemed invalid. Moreover, a lease on agricultural property or part thereof concluded for a period of more than 5 years requires a notarised lease contract. Such an agreement must include a description of the leased out property specifying its surface area, its condition, land class and the condition of the buildings and other facilities, if they are the object of the lease contract. The conclusion of a lease agreement is beneficial to farmers, because according to Art. 9.1. of the Act of 5 August 2015 on Structuring of the Agricultural System, in the event of vending of agricultural property by a natural or a legal person other than the Agency for Restructuring and Modernisation of Agriculture (ARMA), the tenant is entitled under the law to exercise the right of pre-emptive purchase, provided that two conditions are met. The first condition is that the lease agreement must be in writing in the form of a notarial deed and that it has been executed for at least 3 years from the date of submission of the contract to the branch manager of ARMA.

The second condition is that the property purchased must become part of the tenant's family farm. The signing of the lease agreement explicitly solves the problem of who is entitled to submit applications for direct payments to ARMA. The agreement protects farmers against sanctions, should the owner or another applicant submit a direct payment application for the same plot of land. The case is then clear and ARMA does not have to conduct evidentiary proceedings to determine whether an oral lease agreement has truly been concluded, whether it is in force and, finally, who is eligible for subsidies.

\section{REFERENCES}

LEŃ P. 2012. Prawidłowości w rozmiarze występowania gruntów różniczan zamiejscowych na przykładzie wsi w powiecie Brzozów [Patterns in the size of plots belonging to out-of-village owners on the example of villages in Brzozow district]. Infrastruktura i Ekologia Terenów Wiejskich. No. 1/II/2012. Kraków. PAN Oddział w Krakowie p. 137-145.

LEŃ P., MIKA M. 2016a. Determination of the urgency of undertaking land consolidation works in the villages of 
the Sławno municipality. Journal of Ecological Engineering. Vol. 17. Iss. 4 p. 163-169.

LEŃ P., MiKa M. 2016b. The impact of socio-economic factors on the size of the external plot patchwork on the example of Brzustowiec village, in the Łódzkie Voivodship. Geomatics and Environmental Engineering. No. 10/2 p. 43-51.

NoGA K. 1985. Problematyka likwidacji miedzywioskowej szachownicy gruntów. W: Nowe tendencje scalania gruntów indywidualnych w terenach wyżynnych, górzystych i górskich [The issue of liquidation of a village between the patchwork of plots. In: New trends in land consolidation in individual upland, mountain and mountain].Vol. I. Puławy. IUNG p. 143-166.

NoGA K. 2001. Metodyka programowania i realizacji prac scalenia i wymiany gruntów w ujęciu kompleksowym [Methodology of programming and implementation of works consolidation and exchange of land in terms of complex]. Szkoła wiedzy o terenie. Kraków. AR pp. 88.

NoGA K., KRÓL Ż. 2016. The patchwork of land as a problem restricting the development of rural areas. Barometr Regionalny. Vol. 14. No. 3 p. 155-163.

SoBOLEWSKA-MiKULSKA K. 2009. Metodyka rozwoju obszarów wiejskich $\mathrm{z}$ uwzględnieniem wybranych procedur geodezyjnych w aspekcie integracji z Unią Europejską [Methodology of rural development with emphasis on selected procedures surveying in terms of integration with the European Union]. Prace Naukowe Politechniki Warszawskiej. Geodezja. No. 44 p. 3-148.

SoBOLEWSKA-MikULSKA K. 2015. Współczesne scalania gruntów w kształtowaniu granic rolniczej przestrzeni produkcyjne [Modern land consolidation in shaping the boundaries of the agricultural production]. Monografia. Warszawa. Oficyna Wydaw. PW. ISBN 978-83-7814442-7 p. 9-13.
SobolewSKA-MikulSKa K., WóJCiK J. 2012. Aspekty środowiskowe i krajobrazowe rolnictwa w opracowaniu założeń do projektu scalania gruntów [Environmental and landscape of agriculture in the development of assumptions to project land consolidation]. Acta Scientiarum Polonorum. Geodesia et Descriptio Terrarum. Vol. 11 (4) p. 27-38.

StaŃCZUK-GAŁWIACZEK M. 2016. Planowanie małej retencji wodnej w procesie scalenia gruntów na obszarach wiejskich [Small water retention planning in land consolidation projects for rural areas]. Woda-ŚrodowiskoObszary Wiejskie. T. 16. Z. 1 (53) p. 55-69.

TrystuŁA A. 2008. Scalanie gruntów jako jeden z elementów urządzania przestrzeni wiejskiej w Polsce i na Litwie [Land consolidation as one of the elements of rural area development in Poland and Lithuania]. WodaŚrodowisko-Obszary Wiejskie. T. 8. Z. 2a (23) p. 179190.

Ustawa z dnia 23 kwietnia 1964 r. - Kodeks cywilny [Act of 23 April 1964, the Civil Code]. Dz.U. 1964. Nr 16 poz. 93.

Ustawa z dnia 5 sierpnia 2015 r. o kształtowaniu ustroju rolnego [Act of 5 August 2015 on the structuring of the agricultural system]. Dz.U. 2015 poz. 1433.

WóJCIK J. 2012. Prace urządzeniowo-rolne w aspekcie polityki UE na przykładzie wsi Padew Narodowa [Equipment-agricultural work in the context of eu policy on the example of the village Padew Narodowa]. Infrastruktura i Ekologia Terenów Wiejskich. No. 1/II/2012 p. 79-91.

WÓJCIK G., LEŃ P. 2015. Spatial development of agricultural land division throughout the ages in villages of the Opoczno County. Geomatics and Environmental Engineering. Vol. 9/3 p. 95-107.

\section{Przemysław LEŃ}

\section{Rozmiary zewnętrznej szachownicy gruntów wskaźnikiem potrzeb prac scalenia i wymiany gruntów we wsiach gminy Drzewica}

\section{STRESZCZENIE}

Prace scalenia i wymiany gruntów mają znaczący wpływ na poprawę struktury przestrzennej obszarów wiejskich w Polsce. Zważywszy że różne obszary Polski na obszarach rolnych charakteryzują się odmiennymi parametrami przestrzenno-technicznymi, warunkami prawno-własnościowymi do gruntu, konieczne jest przeprowadzenie badań i analiz nad dobraniem optymalnych cech opisujących dany teren. Jak wykazały przeprowadzone badania, obszary centralnej Polski charakteryzują się bardzo wadliwą zewnętrzną szachownicą gruntów. Dlatego też konieczne jest przeprowadzenie analiz w celu określenia rozmiarów zewnętrznej szachownicy gruntów i propozycji jej likwidacji. Jak wynika z przeprowadzonych badań na analizowanym obszarze w pierwszej kolejności powinno się podjąć próbę wymiany gruntów, natomiast kolejnym etapem powinno być przeprowadzenie prac scalenia gruntów.

Słowa kluczowe: grunty różniczan, scalenie gruntów, szachownica gruntów, wymiana gruntów 